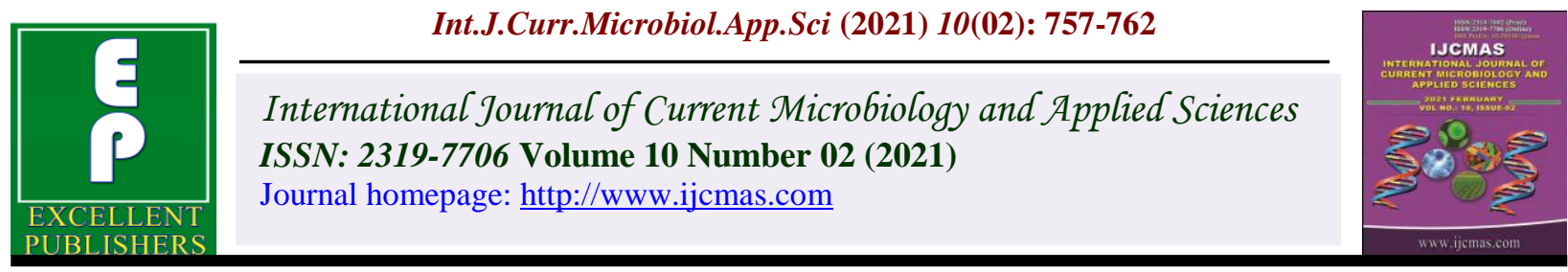

\title{
Assessment of Seasonal Variation in Irrigation Water Quality of Indravati River in Bastar District of Chhattisgarh
}

\author{
Janak Ram Pali, T. Chandrakar*, A. Pradhan, G. K. Sharma, D. P. Singh, \\ Purnima Sahu, Deepika Sahu, Madhuri Dapake and Danish Ahemad Siddiqui
}

Shaheed Gundadhur College of Agriculture and Research Station, Kumhrawand, Jagdalpur, Chhattisgarh (India)

*Corresponding author

\section{A B S T R A C T}

\section{Keywords}

Indravati river water, Irrigation water quality, SAR, RSC, Water quality index

\section{Article Info}

\section{Accepted:}

07 January 2021

Available Online:

10 February 2021
The river Indravati is also known as the oxygen of the Bastar district of state of Chhattisgarh which was considered one of the greenest and eco-friendly districts found in the whole of India. This paper is an attempt to analyze the water quality of river Indravati in Bastar district for irrigation purpose. Water quality variables were measured from water samples collected from six check dams viz. Aasna, Indravati (Kumrawand), Karanji, Rotma, Narayanpal and Chitrakote in the river over a period of one year (June 2019 to March 2020) fortnightly. The samples were analyzed for $\mathrm{pH}, \mathrm{EC}$, TDS, $\mathrm{Ca}, \mathrm{Mg}, \mathrm{Na}, \mathrm{K}, \mathrm{Cl}, \mathrm{CO}_{3}{ }^{2-}, \mathrm{HCO}_{3}{ }^{-}, \mathrm{NO}_{3}{ }^{-}, \mathrm{SO}_{4}{ }^{2-}$. Based on these parameters different irrigation water quality indices such as sodium percent (SP), SAR, RSC and WQI were estimated. Studies of all these characteristics indicate that Indravati river water can be safely used for irrigation round the year.

\section{Introduction}

Indravati River is a stream of the river Godavari. Its starting point is found to be the Ghats of Dandakaranya range, in the Kalahandi district of the state of Odisha rises at an elevation of 914 metres on the western slopes of the Eastern Ghats. It flows westward through the Kalahandi, Nabarangapur and Koraput districts for $164 \mathrm{~km}$ and after forming the boundary between Odisha and Chhattisgarh states for $9.5 \mathrm{~km}$, enters the Bastar district of Chhattisgarh. After flowing $233 \mathrm{~km}$ in Chhattisgarh, it turns south and flows along the boundary of Chhattisgarh and Maharashtra for about $129 \mathrm{~km}$ and joins Godavari River at the junction of the boundaries of Maharashtra, Chhattisgarh and Telangana states. According to Interstate Agreement as per Godavari Water Disputes Tribunal (GWDT) Report, the State of Odisha has to ensure $1.3 \times 10^{9}$ cubic metres $\left(45,000 \times 10^{6} \mathrm{cu} \mathrm{ft}\right)(45 \mathrm{TMC})$ of water at the Odisha-Chhattisgarh border. Now the fall is worth viewing during the rainy seasons only. River Indravati is assigned a Red category on account of an existing Major Dam in Odisha and impending threat from the series of dams 
planned on it as part of lower Indravati power projects in Chhattisgarh. Due to which river flow in Rabi season very limited and majority of the untreated sewage water from Jagdalpur city goes to it, causing water to pollute. Looking to the problem concern we have planned to investigate the "Assessment of seasonal variation in irrigation water quality of Indravati river in Bastar district of Chhattisgarh" with the following objectives to prepare index of irrigation water quality and to estimate the suitability of water for irrigation.

\section{Materials and Methods}

Water samples were collected from six check dams viz. Aasna, Indravati (Kumrawand), Karanji, Rotma, Narayanpal and Chitrakote in $40 \mathrm{~km}$ stretch of the river over a period of one year (June 2019 to March 2020) fortnightly (Fig. 1).

The samples were analyzed for $\mathrm{pH}, \mathrm{EC}$, TDS, $\mathrm{Ca}, \mathrm{Mg}, \mathrm{Na}, \mathrm{K}, \mathrm{Cl}, \mathrm{CO}_{3}{ }^{2-}, \mathrm{HCO}_{3}{ }^{-}, \mathrm{NO}_{3}{ }^{-}, \mathrm{SO}_{4}{ }^{2-}$ by standard procedures (Chopra and Kanwar, 2011). Based on these parameters (Table 2) different irrigation water quality indices such as sodium percent (SP), SAR and RSC were estimated and finally, WQI were estimated as follows-

\section{Water Quality Index (WQI) Calculation}

WQI is a single score derived by considering different important parameters of water quality. It is an integration of the individual effect of all the parameters in right proportion in deciding the quality of water. WQI is generally computed in three steps by several researchers (Water programme, 2007; Ramkrishnaiah et al. 2009). Here a different approach of assigning weightage (Raychaudhuri et al., 2014) was considered to identify and highlight the location specific reasons for contamination of water.
At first each parameter was assigned a weight (wi) according to its relative importance in the overall quality of water for drinking purposes based on per cent of samples within the permissible limit as per the standards. Weights of 5, 4, 3, 2, 1 are assigned to the quality parameters when 0-20, 21-40, 41-60, 61-80 and $81-100 \%$ of samples are within the permissible limit respectively (Raychaudhuri et al., 2014).

Secondly, the relative weight (Wi) is computed from using the following equation:

$\mathbf{w i}=\frac{\mathbf{w i}}{\sum_{1=1}^{n} \mathbf{w i}} \quad \ldots \ldots \ldots$ (1)

where, Wi is the relative weight, wi is the weight of each parameter and $n$ is the number of parameters. Third step involves assignment of a quality rating scale (qi) for each parameter by dividing its concentration in each water sample by its respective standard according to the guidelines laid down in the BIS followed by multiplication with 100 :

$\mathrm{qi}=(\mathrm{Ci} / \mathrm{Si}) \times 100$

where qi denotes the quality rating, $\mathrm{Ci}$ denotes the concentration of each chemical parameter in each water sample in $\mathrm{mg} / \mathrm{L}$, and $\mathrm{Si}$ is the Indian drinking water or irrigation water standard for each chemical parameter in $\mathrm{mg} / \mathrm{L}$ according to the guidelines of the BIS 10500, 1991 or FAO respectively (Table 1). For computing the WQI, the SI is first determined for each chemical parameter, which is then used to determine the WQI as per the following equation.

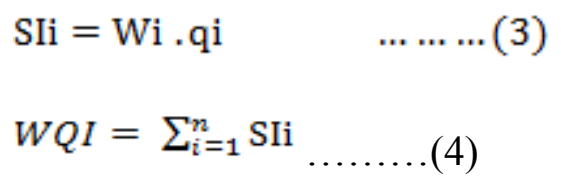

Sli is the sub-index of $i^{\text {th }}$ parameter; qi is the rating based on concentration of ith parameter 
and $\mathrm{n}$ is the number of parameters. The computed WQI values are then categorised into four classes based on "none", "slight", "moderate" and "severe" restrictions for irrigation use (Table 3). The WQI identifies the causative element or group of parameters responsible for the deteriorated quality so that appropriate measures can be implemented for its restoration.

\section{Results and Discussion}

\section{Water Quality Index (WQI)}

Water of adequate quantity and acceptable quality is essential for the sustenance of life. In order to assess the suitability of water for irrigation in the study area of Bastar District, WQI is a single score derived by considering different important parameters of water quality. It is an integration of the individual effect of all the parameters in right proportion in deciding the quality of water.
WQI of water at all the six study sites showed a range of 44.57 to 89.82 with mean and SD of 66.26 and 9.11, respectively (Fig. 2) and was found excellent water in terms of WQI for irrigation. The $13.75 \%$ variability found in WQI of river water at different sampling locations of Bastar district. The highest WQI was found in the Aasna checkdam (89.82) in the month of February followed by Karanji checkdam in the month of February (82.52), Indravati (80.16), Rotma checkdam (78.14) and lowest WQI (44.57) was found in the month of August in Karanji checkdam. The box plot showed that the distributions of WQI data are useful in visualizing skewness in the WQI of water (Fig 4). Mean values were taken into consideration as characteristic values to see the differences during three seasons (Fig 3). The average values of WQI recorded highest in summer (86.73) compare to rainy (68.22) and winter (59.55).

Table.1 FAO standard for individual parameters for irrigation use and weightage assigned

\begin{tabular}{|l|l|l|l|l|l|}
\hline Parameters & Units & $\begin{array}{l}\text { FAO } \\
\text { standards }\end{array}$ & $\begin{array}{l}\text { \% } \\
\text { Compliance }\end{array}$ & Weight & $\begin{array}{l}\text { Relative } \\
\text { weight }\end{array}$ \\
\hline $\mathbf{p H}$ & - & $6.0-8.5$ & 67 & 2 & 0.13 \\
\hline $\mathbf{E C}$ & $\mu \mathrm{S} / \mathrm{cm}$ & $1000^{*}$ & 100 & 1 & 0.06 \\
\hline $\mathbf{S A R}$ & - & 3 & 100 & 1 & 0.06 \\
\hline $\mathbf{C O}_{3}{ }^{2-}$ & $\mathrm{ppm}$ & 60 & 100 & 1 & 0.06 \\
\hline $\mathbf{H C O}_{\mathbf{3}}^{-}$ & $\mathrm{ppm}$ & 610 & 100 & 1 & 0.06 \\
\hline $\mathbf{C l}$ & $\mathrm{ppm}$ & 1065 & 100 & 1 & 0.06 \\
\hline $\mathbf{N O}_{3}^{-}-\mathbf{N}$ & $\mathrm{ppm}$ & $45^{* *}$ & 100 & 1 & 0.06 \\
\hline $\mathbf{S O}_{\mathbf{4}}{ }^{2-}-\mathbf{S}$ & $\mathrm{ppm}$ & 1920 & 100 & 1 & 0.06 \\
\hline $\mathbf{T o t a l} \mathbf{H a r d n e s s}$ & $\mathrm{ppm}$ & 1000 & 100 & 1 & 0.06 \\
\hline $\mathbf{C a}$ & $\mathrm{ppm}$ & 400 & 100 & 1 & 0.06 \\
\hline $\mathbf{M g}$ & $\mathrm{ppm}$ & 60 & 100 & 1 & 0.06 \\
\hline $\mathbf{N a}$ & $\mathrm{ppm}$ & 920 & 100 & 1 & 0.06 \\
\hline $\mathbf{K}$ & $\mathrm{ppm}$ & 2 & 67 & 3 & 0.19 \\
\hline & & & Total & 16 & \\
\hline
\end{tabular}

*Full yield potential is obtained for nearly all crops when using irrigation water less than $1.0 \mathrm{dSm}-1$

**Mostly Indian soils are low in $\mathrm{N}$ content so the permissible limit for drinking water quality parameter is considered 
Table.2 Chemical parameters of Indravati river water in Bastar district during 2019-20

\begin{tabular}{|c|c|c|c|c|c|}
\hline Parameter & Minimum & Maximum & Mean & SD & CV \% \\
\hline pH & 6.99 & 9.09 & 7.74 & 0.64 & 8.25 \\
\hline $\mathrm{EC}(\mathrm{dS} / \mathrm{m})$ & 0.06 & 0.25 & 0.13 & 0.05 & 37.10 \\
\hline TDS(ppm) & 254.2 & 381.2 & 302.75 & 30.89 & 10.20 \\
\hline $\mathrm{HCO}_{3}^{-}(\mathrm{meq} / \mathrm{l})$ & 0.745 & 6.66 & 2.69 & 1.41 & 52.24 \\
\hline $\mathrm{Ca}(\mathrm{meq} / \mathrm{I})$ & 0.9 & 4.2 & 2.11 & 0.83 & 39.30 \\
\hline $\operatorname{Mg}(\mathrm{meq} / \mathrm{l})$ & 0.4 & 1.45 & 0.84 & 0.32 & 38.45 \\
\hline $\mathrm{Na}(\mathrm{meq} / \mathrm{l})$ & 0.17 & 0.43 & 0.26 & 0.06 & 23.75 \\
\hline K(meq/l) & 0.06 & 0.14 & 0.10 & 0.02 & 16.53 \\
\hline $\mathrm{NO}_{3}^{-}(\mathrm{ppm})$ & 0.56 & 19.94 & 5.68 & 4.87 & 85.72 \\
\hline $\mathrm{SO}_{4}{ }^{2-}(\mathrm{ppm})$ & 0.3 & 3.25 & 0.93 & 0.65 & 69.92 \\
\hline $\mathrm{Cl}(\mathbf{p p m})$ & 1.90 & 20.66 & 9.16 & 5.10 & 55.69 \\
\hline $\mathrm{Na}(\%)$ & 4.41 & 32.78 & 15.18 & 7.04 & 46.41 \\
\hline SAR & 0.14 & 0.44 & 0.23 & 0.06 & 27.57 \\
\hline RSC(meq/l) & -2.05 & 3.70 & -0.26 & 2.06 & 79.1 \\
\hline
\end{tabular}

Table.3 Classification of surface water quality for irrigation use based on WQI

\begin{tabular}{|l|l|l|l|}
\hline WQI & Class & Restrictions & \% of water samples \\
\hline$<\mathbf{1 5 0}$ & I & None & $100 \%$ \\
\hline $\mathbf{1 5 0 - 3 0 0}$ & II & Slight & - \\
\hline $\mathbf{3 0 0 - 4 5 0}$ & III & Moderate & - \\
\hline $\mathbf{> 4 5 0}$ & IV & Severe & - \\
\hline
\end{tabular}

Fig.1 Map of River Indravati showing sampling sites

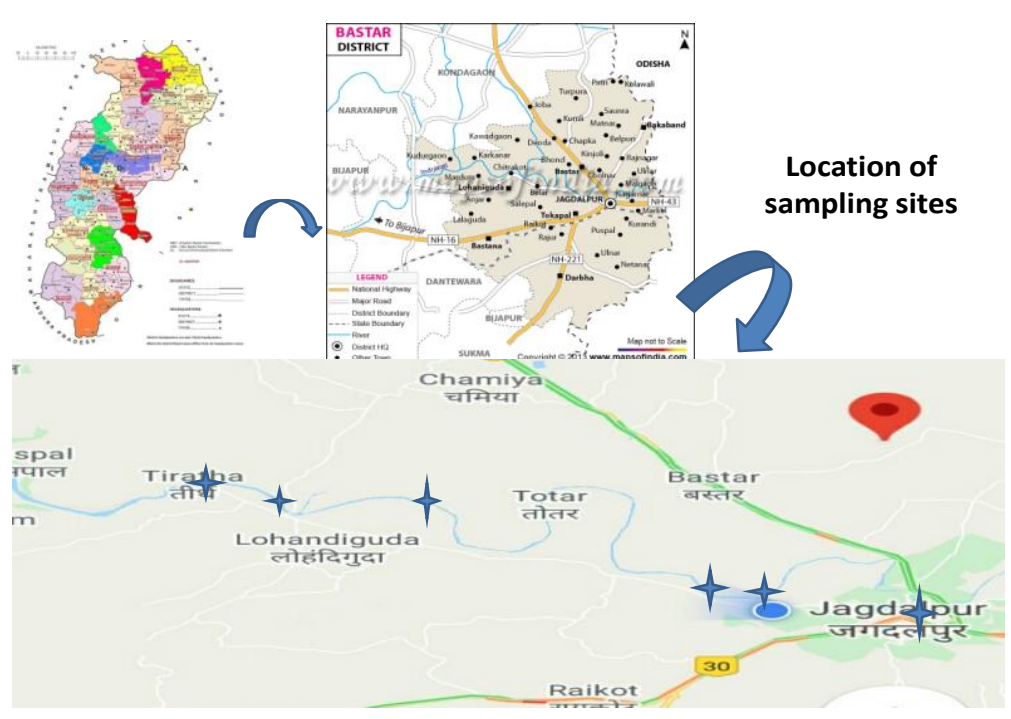


Fig.2 Site wise WQI variation in surface river water of Indravati during different months

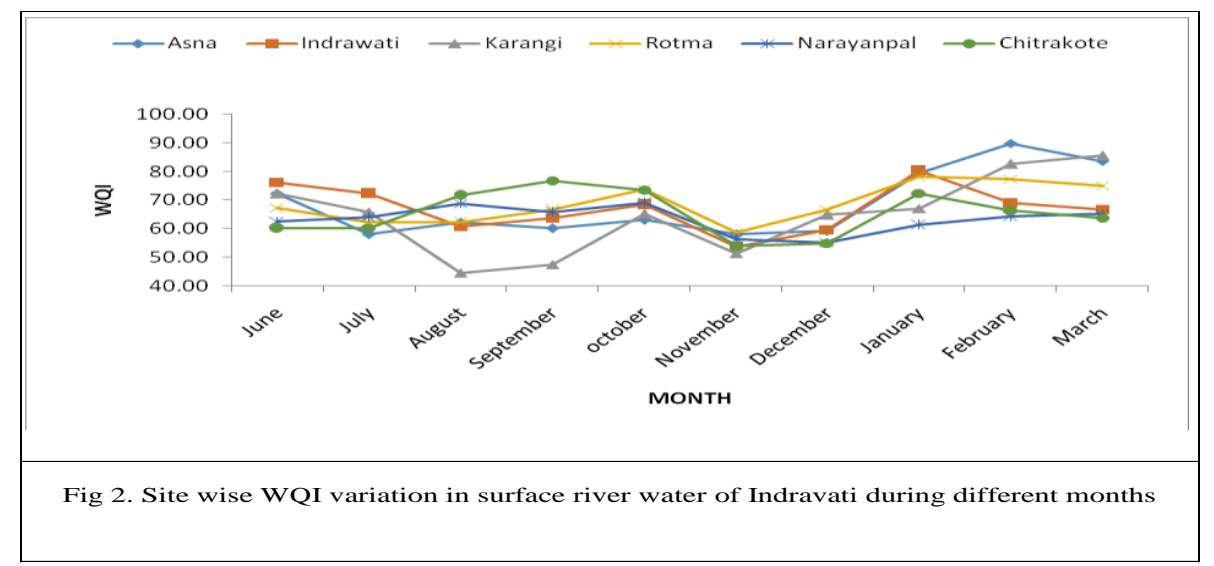

Fig.3 Seasonal WQI variations in surface river water of Indravati in Bastar

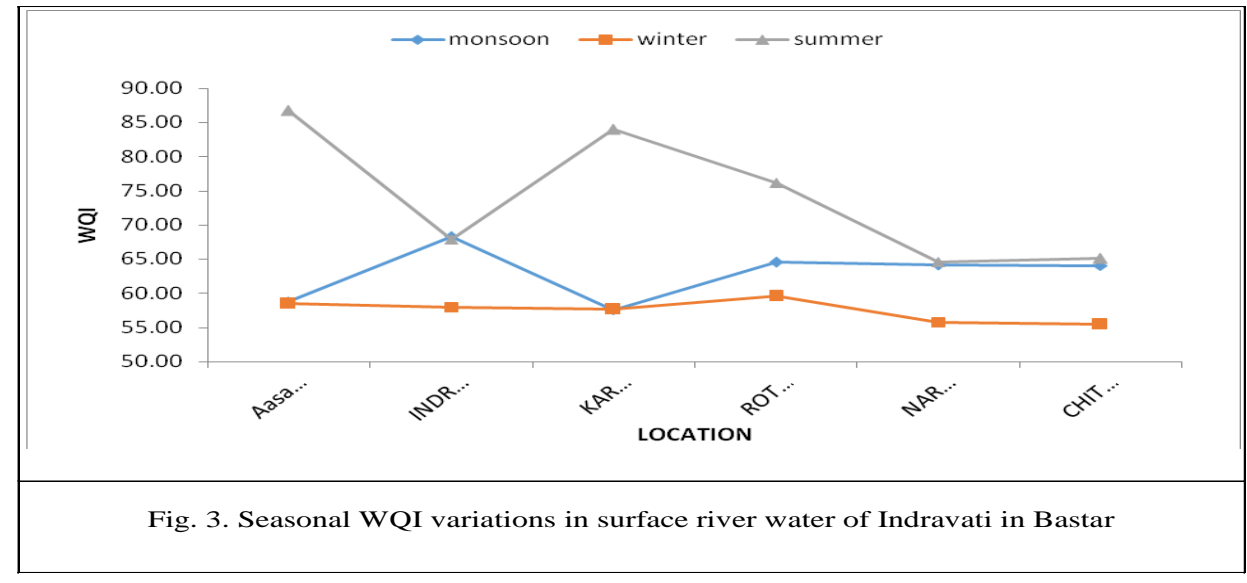

Fig.4 Box plot of monthly WQI of river Indravati in Bastar District in Chhattisgarh

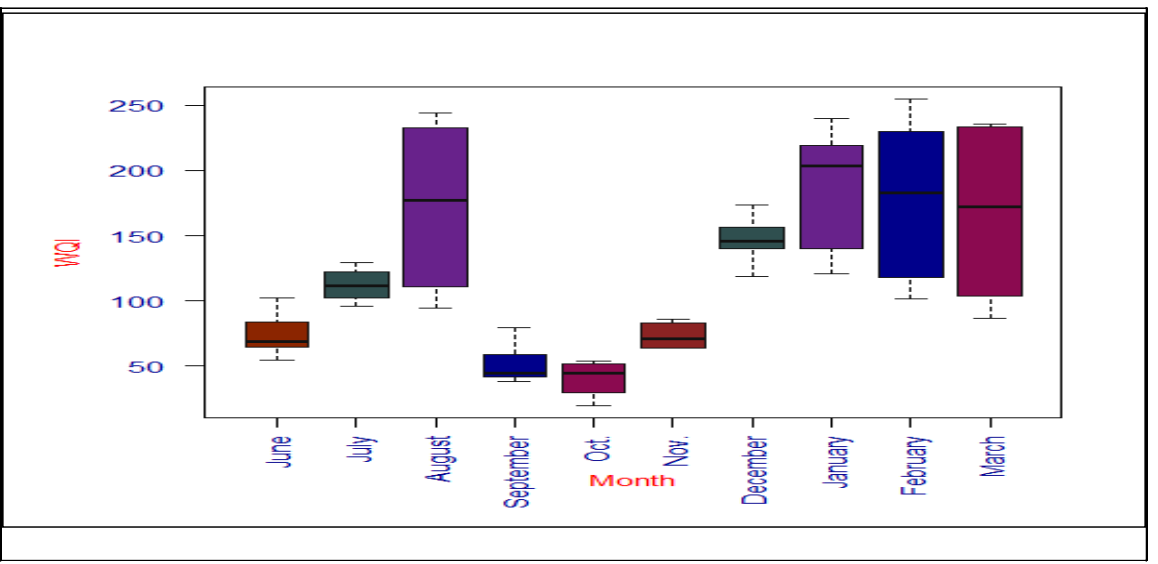


The higher WQI during summer was due to more $\mathrm{Na}$ and $\mathrm{NO}_{3}{ }^{-}$concentration and in rainy season, it may be due to soil erosion, mixing of domestic and agricultural discharges due to heavy rain and other anthropogenic activities as mentioned by Parmar and Parmar (2010). As per classification, the calculated values of WQI at all the six study sites was less than 150 , the water can be safely used for irrigation with none restrictions round the year.

In conclusion the water quality status is assessed through Weighted Arithmetic Index method. WQI values of surface water samples analyzed for pre and post monsoon seasons depict that there exists a narrow change in the WQI values which is not vary significantly with reference to irrigation water quality. As per WQI scale, the river water at various stations was classified excellent to good for irrigation.

\section{Acknowledgement}

We are thankful to All India Coordinated Research Project for Dryland Agriculture, SG College of Agriculture and Research Station, Jagdalpur centre for providing the support during the study.

\section{References}

Chopra S.L. and Kanwar J.S. 2011.Analytical Agricultural Chemistry. Analysis of irrigation water. Kalyani Publishers, Fourth Edition 1991, reprinted 2011.
277-298.

Parmar K. and Parmar V.2010. Evaluation of water quality index for drinking purposes of river Subernarekha in Singhbhum District. International Journal of Environmental Sciences. Vol 1(1): 77-81.

Ramakrishnaiah, C. R., Sadashivaiah, C. and Rangana, G. 2009. Assessment of Water Quality Index for the Groundwater in Tumkur Taluk, Karnataka State, India E-Journal of Chemistry http://www.ejournals.net, 6(2), 523-530.

Raychaudhuri, M. Raychaudhuri S., Kumar, A., Jena, S. K., and Choudhury, A. 2014. Water Quality Index to Monitor Water Quality of Rushikuliya Canal Command Area for Irrigation and Potable Use. In Volume of Papers. One Day Workshop on Augmentation and Conservation of Groundwater Resources of Odisha (Eds: P. K. Mohapatra, D. N. Mandal., A. Choudhury, and G. Vijayakumar), Central Ground water Authority and Central Ground water Board, South Eastern Region, Bhubaneswar, pp. 140147.

Water Programme 2007. Global Drinking Water Quality Index Development and Sensitivity Analysis Report. Prepared and published by the United Nations Environment Programme and Global Environment Monitoring System (GEMS)/Water Programme.

\section{How to cite this article:}

Janak Ram Pali, T. Chandrakar, A. Pradhan, G. K. Sharma, D. P. Singh, Purnima Sahu, Deepika Sahu, Madhuri Dapake and Danish Ahemad Siddiqui. 2021. Assessment of Seasonal Variation in Irrigation Water Quality of Indravati River in Bastar District of Chhattisgarh. Int.J.Curr.Microbiol.App.Sci. 10(02): 757-762. doi: https://doi.org/10.20546/ijcmas.2021.1002.090 